\title{
HIBAH BINA DESA PENERAPAN TEKNOLOGI PENGOLAHAN ECENG GONDOK SEBAGAI PAKAN TERNAK DAN INDUSTRI KERAJINAN RUMAH TANGGA DI KELURAHAN LEMPAKE
}

\author{
Nursyam, Akmal Dzuhri, Nova Andreanto Putro, Ratna, Lulu Khizanatusani, Sri \\ Maryati. Luthfika Zyahratul Ula, Nirmala Aggraini, M. Alam Syah, Riyo Wijaya, \\ Fauzin, Mujiantoro, Emillia Poni Yang Dalah, Marianus Ermen, Fitri Ismiyati \\ Ramadani, Arif Ismanto \\ Fakultas Pertanian, Universitas Mulawarman \\ Email :arifismanto9@gmail.com
}

\begin{abstract}
The aim of the Village Development Grant Program is to make efforts to empower the Lempake village community to use water hyacinth processing technology as animal feed and home industry in order to reduce sedimentation of Benanga reservoirs and increase the productivity of the community of Lempake village. Factors that trigerring this activity are the low of knowledge and skill data of comunity to optimize the potention of water hyacinth that become one of the keys in the reservoir in the kelurahan where the activity is located. Target Activities This Village Development Grant is a PKK group from the Lempake Village and the Subur Livestock Group. The main method in this activity is training and monitoring. Water hyacinth processing training produces several types of crafts (bags, tissue boxes and pillows) and the formation of community business groups, Egona Mulawarman. Meanwhile, to train feed cattle, water hyacinth using to make silage. The working relationships that exist include the City of Samarinda Industry Agency, and the Samarinda City Agriculture Service.
\end{abstract}

Keywords : Empowerment, Water Hyacinth, Village Development Grants Program, handicrafts and silage.

\section{PENDAHULUAN}

Lempake merupakan salah satu kelurahan yang berada di wilayah Kecamatan Samarinda Utara. Kelurahan ini memiliki luas wilayah seluas 32,83 $\mathrm{Km}^{2}$ dengan jumlah penduduk sebanyak 16.363 jiwa (BPS Kota Samarinda, 2017) . Di desa ini, terdapat sebuah waduk yaitu Waduk Benanga dengan luas 387,10 Ha dengan kedalaman air sekitar 2 meter.
Waduk benanga adalah salah satu kontruksi yang dibangun untuk menahan laju air dan merupakan salah satu sumber air yang berada di Kota Samarinda. Disamping itu waduk ini juga menjadi salah satu obyek pariwisata. Seiring berjalannya waktu fungsi dari waduk ini mulai kurang optimal. Menurut data Konsultan Sumber Daya Air (SDA) Dinas Pekerjaan Umum (PU) Kalimantan Timur tahun 2001, Waduk Benanga 
mampu menampung 1,4 juta meter kubik air, akan tetapi pada tahun 2010, kapasitasnya mulai mengalami penurunan menjadi 767 ribu meter kubik, dan kembali menyusut pada tahun 2015 yakni tinggal 560 meter kubik. Ketika musim hujan debit air Waduk Benanga ketinggiannya dapat melebihi palang pintu, menyebabkan air meluap dan menggenangi kawasan yang lebih rendah sehingga menyebabkan banjir di beberapa kawasan Kota Samarinda. Salah satu faktor yang menjadi penyebab hal tersebut adalah terbentuknya sedimentasi akibat banyaknya tumbuhan air berupa eceng gondok yang memenuhi hampir seluruh bagian Waduk.

Keberadaan eceng gondok di waduk Benanga menyebabkan menurunnya jumlah cahaya yang masuk ke dalam perairan waduk, mempercepat terjadinya proses pendangkalan, dan mengganggu lalu lintas (transportasi) air. Sejauh ini banyak program pembersihan wilayah waduk benanga yang dilaksanakan oleh pemerintah daerah namun belum efektif.

Pemanfaatan tumbuhan eceng gondok dapat menjadi solusi dari permasalahan yang telah disampaikan pada paparan sebelumnya. Pemanfaatan tumbuhan eceng gondok akan berimplikasi pada berkurangnya jumlah eceng gondok secara terus menerus dikarenakan kebutuhan akan tumbuhan ini sebagai sumber bahan baku. Dua alternatif penerapan teknologi yang akan dikembangkan sebagai kegiatan Tim Program Hibah Bina Desa (PHBD) yaitu pengolahan eceng gondok sebagai pakan ternak dan pengolahan eceng gondok sebagai bahan baku industri kerajinan rumah tangga.

\section{KHALAYAK SASARAN}

Khalayak sasaran dalam program ini adalah kelompok PKK Keluraha Lempake dan Kelompok Ternak Subur.

\section{METODE PELAKSANAAN}

Kegiatan utama pengabdian pada masyarakat di Kelurahan Lempake terdiri dari 1) pelatihan, 2) pendampingan dan 3) evaluasi. Pelatihan kerajinan eceng gondok dilaksanakan pada tanggal $3-5$ September 2018, sedangkan pelatihan pembuatan pakan ternak diadakan pada tanggal 5 Oktober 2018. 


\section{HASIL DAN PEMBAHASAN}

Sebelum pelatihan, kegiatan diawali dengan hasil survey yang dilakukan tim PHBD Himpunan Mahasiswa Peternakan Universitas Mulawarman ke waduk Benanga. Berdasarkan survey tersebut dapat dipetakan permasalahan yang ada yaitu bahwa terdapat banyak populasi enceng gondok yang memenuhi permukaan waduk yang mengganggu fungsi waduk dan belum dilakukannya pemanfaatan atau tindakan pengelolaan terhadap eceng gondok yang ada di waduk tersebut.

Setelah dilakukannya observasi lebih lanjut diputuskan bahwa enceng gondok di waduk Benanga berpotensi untuk bahan baku berbagai kerajinan (handycraft) dan juga potensial untuk digunakan sebagai alternatif pakan ternak.

Kegiatan berikutnya yaitu sosialisasi yang terbagi menjadi dua tahap yaitu : sosialisasi mengenai pemanfaatan eceng gondok sebagai bahan utama kerajinan tangan pada tanggal 25 Juli 2018 dan untuk sosialisasi kedua mengenai pemanfaatan eceng gondok sebagai pakan ternak berupa silase pada tanggal 13 Agustus 2018. Pada tahap sosialisasi ini dilakukan penyampaian tentang latar belakang program serta memberikan gambaran umum mengenai tatacara pembuatan pakan silase serta kerajinan enceng gondok melibatkan masyarakat untuk berpartisipasi aktif dalam kegiatan pemberdayaan masyarakat yang ada.

Kegiatan selanjutnya yaitu launching program. Kegiatan ini dimaksudkan sebagai media untuk komunikasi beberapa pihak yang terkait dengan program yaitu : universitas, kelurahan Lempake, Dinas Perindustrian dan Dinas Pertanian Kota Samarinda.

Usaha membangun kemitraan dengan Dinas-dinas terkait yang dilakukan melalui launching program adalah untuk memudahkan dalam monitoring dan pelaksanaan program selanjutnya (Graha, 2011).

Kegiatan berikutnya yaitu Pelatihan. Pelatihan dilakukan dalam 2 tahap pula yaitu pelatihan pembuatan kerajian eceng gondok pada tanggal 3- 5 september 2018 yang melibatkan mitra yaitu IKM YL Handycraft Yogyakarta sebagai pembina yang keberadaannya di bawah naungan Disperindagkop Provinsi Daerah Istimewa Yogyakarta. 
Melalui pengalaman dan jaringan yang dimiliki oleh mitra, yaitu hubungan baik dengan Kementrian Perindustrian dan Perdagangan RI diharapkan dapat memacu perkembangan kerajinan eceng gondok di Samarinda khususnya Kelurahan Lempake. Disamping itu, koordinasi yang intens antara mitra, Tim PHBD dan Dinas Perindustrian Kota Samarinda memacu terbentuknya sentra encong gondok di Kelurahan Lempake.

Melihat budaya Kalimantan Timur yang kaya akan kesenian berupa anyaman manik-manik yang diakui terbaik di seluruh Indonesia, menggerakkan masyarakat untuk berinovasi dengan mengkombinasikan kreasi anyaman enceng gondok dengan manik - manik khas Kalimantan Timur. Hal ini dapat menjadi ciri khas tersendiri dalam sentra kerajinan Enceng gondok yang sudah ada di pasaran, bahwa Kalimantan Timur juga mempunyai Kerajinan dari enceng gondok yang unik dan dapat bersaing dunia pemasaran.

Tahap berikutnya dari kegiatan pelatihan adalah penguatan kelembagaan. Dalam rangka meningkatkan kekuatan kelembagaan, Tim PHBD ibu-ibu PKK kelurahan
Lempake menginisiasi terbentuknya kelompok usaha masyarakat yang diberi nama EGONA Mulawarman (Enceng Gondok Benanga Mulawarman).

Pelatihan tahap kedua yaitu pelatihan menggnai pembuatan pakan ternak silase yang dilakukan pada tanggal 5 Oktober 2018 di Kelompok Ternak Subur. Pelatihan ini dilakukan dengan melibatkan dosen di Fakultas Pertanian sehingga pembuatan pakan ternak lebih akurat dan tepat. Pelatihan ini diharapkan dapat menjadi pintu bagi peternak dalam meningkatkan kegiatan usaha peternakan sapi yang dimiliki menjadi lebih efisien.

Beberapa kendala yang dimiliki oleh peternak yaitu modal, pakan dan pemasaran. Pelatihan pembuatan pakan ini menjadi salah satu upaya mengatasi permasalahan yang ada.

\section{FOTO KEGIATAN}

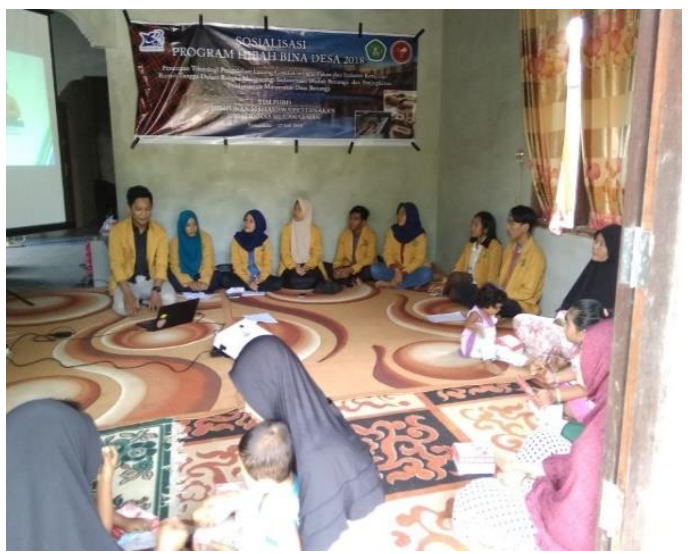

Suasana pada saat sosialisasi program kepada ibu-ibu PKK 


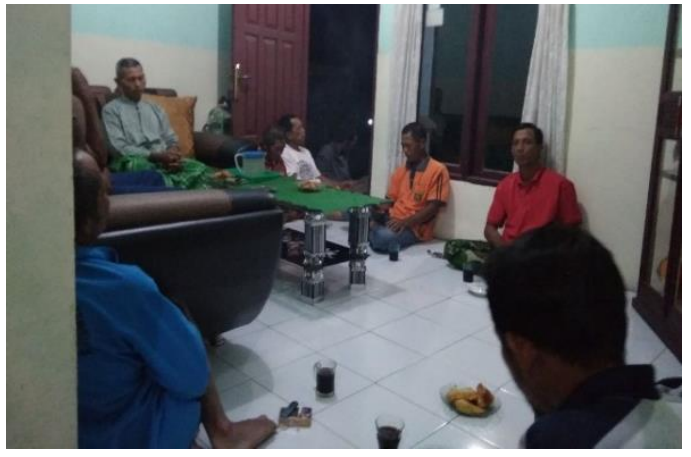

Kegiatan sosialisasi dengan peternak Subur

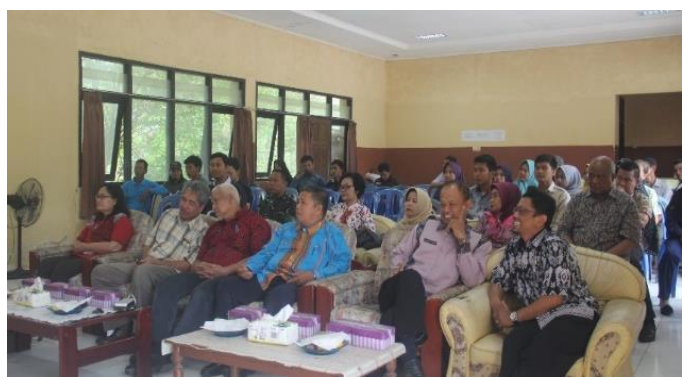

Launching Program Hibah Bina Desa 2018

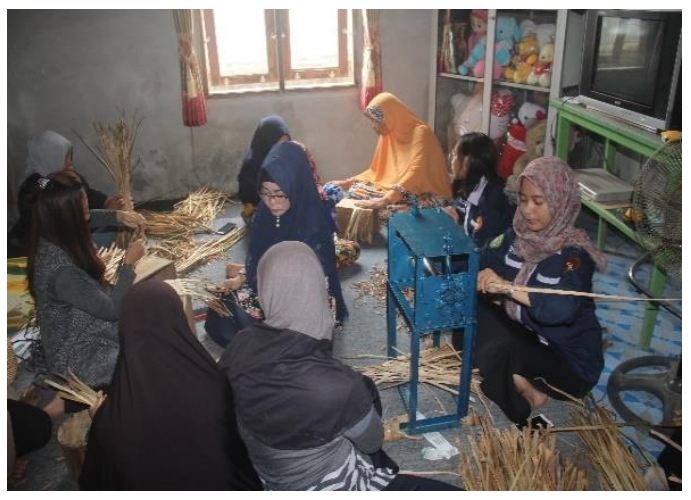

Kegiatan pelatihan pembuatan kerajinan eceng gondok

\section{UCAPAN TERIMAKASIH}

Direktorat Jenderal Pembelajaran dan

Kemahasiswaan, Kementerian Riset, Teknologi dan Pendidikan Tinggi.

\section{KESIMPULAN}

1. Kegiatan program hibah bina desa ini berjalan dengan baik dan tepat sasaran.

2. Hasil dari kegiatan ini mendapat respon baik pada masyarakat dan juga pemerintah dalam pengembangannya.

3. Pengelolaan serat alami seperti eceng gondok dapat bedampak baik pada lingkungan dan juga bernilai ekonomis.

\section{DAFTAR PUSTAKA}

BPS Kota Samarinda. 2018. Kota Samarinda dalam Angka 2017. Kota Samarinda

Anonim. 2017. Sedimen waduk Benanga terus Menumpuk. Kaltim Post diakses tanggal 3 Oktober 2018 http://kaltim.prokal.co/read/news 1296041-sedimen-waduk-terusmenumpuk.html

Graha, A. (2011). Peranan UKM Menjalin Kemitraan Guna Memperluas Jaringan, Pengembangan Media Dan Sarana Berbisnis. Jurnal Ekonomi Modernisasi, 7(1), 123. Retrieved from http://ejournal.unikama.ac.id/ind ex.php/JEKO/article/view/44 